\title{
Chinese Youth Nationalism in a Pressure Cooker
}

\author{
Rou-lan Chen
}

The first decade of the twenty-first century witnessed an explosion of anger among Chinese youth. ${ }^{1}$ In contrast to the peasants and workers who erupted in anger over their marginalization from China's economic boom, the flame of the raging youth (fenqing) burned in the name of patriotism. In the wake of the 1999 bombing of the Chinese embassy in Belgrade, the 2001 China-US aircraft collision, the 2008 Beijing Olympics, and the 2012 disputes over the Diaoyu Islands (referred to as the Senkaku Islands by Japan), the power of spontaneous mass protest spread like a raging fire to include an enormous number of students, particularly in September 2012, when the Japanese government purchased the Diaoyu Islands, triggering indignant protests in as many as one hundred cities in China. Hundreds of thousands of young people participated in massive rallies and took to the streets with violence, vandalism, and arson. In fact, the dispute over the Diaoyu Islands was not new. It had been recurring over the previous three decades. In 1972, at the end of the American occupation of Okinawa, the Japanese government resumed its administration of the Diaoyu Islands, sparking the dispute, which never burnt out. For the first time, the Republic of China (ROC) officially claimed the Diaoyu Islands as a part of Taiwan, which presumably should have been returned to Chinese jurisdiction in 1972. To dispute the original Japanese claim of sovereignty over the Diaoyu Islands, massive student national movements erupted in Taiwan through the 1970s. In 1996, when Japanese right-wingers erected a lighthouse on the main island, protesters in Taiwan and Hong Kong again marched through the streets and attempted to land on the Diaoyu Islands.

It was the first time as well that the Kuomintang (KMT) government allowed a large-scale student movement in Taiwan. The dilemma was that nationalism 
inevitably triggered social mobilization, which, if uncontrolled, could easily be turned against the authoritarian KMT regime. In a sense, the youth nationalism of the 1970s was revived by the KMT as a displacement of affect over the diminishing legitimacy of Chinese identity in Taiwan. The 1970 s saw a switch in diplomatic recognitions from the ROC to the People's Republic of China (PRC). At the same time, Taiwan's economic growth was accompanied by rising pressure for farreaching changes in governance. However, with the KMT government tightly restricting political participation, young people had nowhere to voice their anxieties and to reassert their identity. To reclaim the legitimacy of the KMT and maintain political stability, the KMT instigated nationalism with a clear enemy (Japan) as an efficient strategy to divert youth's attention from the legitimacy problem and to elicit political support. Hence, the Diaoyu Islands functioned as a condensation symbol for irredentist nationalism, on the basis of a discourse of Chinese territory being taken away from the self by Japan. Through new editions of geographic maps and historical textbooks in 1972, the Diaoyu Islands were constructed as China's lost land. In short, the 1972 Diaoyu Islands movement arose from Taiwan's international isolation coupled with its fast-growing economy, which led to a state of anomie in which young people suffered from identity crisis and powerlessness in the market economy. ${ }^{2}$ Therefore, it is reasonable to infer that in the 2000 s the weakening hold of Chinese identity in Taiwan and the Taiwan-centered pedagogy found in school curricula tended to deflate enthusiasm for the movement to protect the Diaoyu Islands (Baodiao), which the younger generation in Taiwan associated with support for cross-Strait reunification. ${ }^{3}$ We hardly see online antiJapan protests among Taiwan's youth before Japan's 2012 nationalization of the Diaoyu Islands.

Before 2012, the Chinese Communist Party (CCP) remained at a distance from the dispute. When the first two waves of protests over the Diaoyu Islands flared in 1972 and 1996, major anti-Japanese demonstrations were held in Taiwan and Hong Kong but not in Beijing. The authorities in China suppressed xenophobia and decided to "shelve the dispute" to be resolved in the future. ${ }^{4}$ Why was Chinese youth nationalism regarding the Diaoyu Islands disputes revived in 2012? Some observers attributed the rise of Chinese nationalism to the state's construction. They regarded the new nationalism of the post-1980 generation as "official nationalism" or "pragmatic nationalism," anchored in a patriotic ethos that looked to the CCP as a guardian of the national interest. ${ }^{5}$ Specifically, they saw it as the creation of the CCP's "Patriotic Education Campaign" of the 1990s and 200os, which attempted to shore up the party's declining legitimacy by focusing on China's historic glory and the subsequent "hundred years of humiliation," through repeated submission to foreign powers, that began with the First Opium War in the nineteenth century. ${ }^{6}$ They also noted that, by using the United States as a reference group, the authorities aroused xenophobia to consolidate the communist regime. ${ }^{7}$ Other scholars 
believed that the 1990 s witnessed as well the emergence of a popular nationalism that should not be conflated with official nationalism. Unable to suppress the protesters, the CPP was losing control over nationalist discourse and was forced to plead with protesters. ${ }^{8}$ Increasingly scholars also related grassroots nationalism to the rise of the Internet, which unified the Chinese cyber community against foreign pressure. Chinese cyber nationalists have been utilizing the Internet as a communication center, organizational platform, and implementation channel for their cause. ${ }^{9}$

However, without knowing the mind-set of Chinese youth, we cannot explain why in 2012 the once unimportant Diaoyu Islands became an indivisible part of China for the younger generation. Why did protests over the Diaoyu Islands spread so rapidly and then turn violent? To explore these questions, this chapter is divided into two parts. The first part aims at investigating the process by which the Diaoyu Islands made their way into the imagination of the younger generation. In the process of identity construction, Taiwan and Japan served as important reference groups for Chinese youths. The second part hinges on why Chinese youth movements took a nationalist turn and galvanized millions in the disputes over the Diaoyu Islands in 2012. In many ways China's situation was analogous to the crisis over the Diaoyu Islands in Taiwan in 1972. Specifically, I posit that the "raging youth" phenomenon derives from ambivalence between national pride and disappointment in the CCP. What made the post-1980 generation proud yet ashamed? This chapter brings to light the structural factors that facilitated the youth movements in 2012. After three decades of economic reform, the CCP still has a tight grip on the political system and legitimates itself by maintaining high economic growth. I will show how China's youth, given a limited organizational life, sanctioned or monitored by the state, found in the Internet a public space in which to vent their anger, circulate ideas, and engage in civil actions, all of which aided their collective pursuit of national identity. Finally, we show how interactions between the Internet and globalization precipitated the resurgence of an outraged nationalism in contemporary China. Globalization unavoidably brings people together, and this paper investigates why, in an age boasting an upsurge in Internet access, Chinese identity is always affirmed against a foreign enemy.

\section{WHY THE DIAOYU ISLANDS?}

Before we begin the analysis of the "raging youth" phenomenon in 2012, it is crucial to know when and how Chinese youth expanded their imagination of China's boundaries to the Diaoyu Islands. As in Taiwan in the 1970s, the authorities made the Diaoyu Islands a part of the imagined community for Chinese youth to ensure their own legitimacy and adjust to the changing international and domestic conditions. 


\section{Shelving the Dispute}

In 1968, the discovery of massive oil deposits near the East China Sea for the first time put the Diaoyu Islands in the spotlight. Before then, neither China nor Taiwan had shown any interest in these uninhabited and barren islands. The dispute over the Diaoyu Islands was sparked in 1972, when the United States turned over administrative rights of the islands to Japan, as stipulated by the Okinawa Reversion Treaty. The core of the controversy lay in whether the Diaoyu Islands had belonged to Taiwan in April 1895, at which time, under the Shimonoseki Treaty, the Chinese (Qing) government had ceded Taiwan and "all islands pertaining to it" to Japan. With the end of the Second World War, all Chinese-ceded territory had to be returned to China, according to the provisions of the Cairo Declaration of 1943, the Potsdam Proclamation of 1945, and the Treaty of Peace with Japan of 1952. Both the PRC and the ROC claimed the Diaoyu Islands as a part of Taiwan, which presumably should have been returned to Chinese jurisdiction in 1972.

Japan originally claimed sovereignty over the Diaoyu Islands in 1884 on the basis of the principle of terra nullius and incorporated them into Japan in January 1895. In protest, massive student national movements erupted in Taiwan and Hong Kong through the 1970s but, surprisingly, not in Beijing. Between 1966 and 1976, Chinese young people were embroiled in the Cultural Revolution, with a large number of urban youth being transferred to rural regions through the Down to the Countryside Movement. Even though schools resumed regular schedules in 1978 , the curriculum in the 198 os was dominated by revolutionary views with the purpose of restoring the CCP's legitimacy. ${ }^{10}$ Hence, the Chinese Cultural Revolution and Reform generations were not concerned with the Diaoyu Islands. More importantly, in the 1970s, both Japan and the United States were in the midst of approaching China to normalize diplomatic relations. Given his keen interest in having the PRC replace the ROC as the only legitimate representative of China in the international arena, Deng Xiaoping decided to downplay the sovereignty dispute with Japan and leave the issue to future generations in 1972 and 1978.

\section{The Shadow of Taiwan and Japanese Actions}

After three decades of silence, the CCP started to voice its concern over the Diaoyu Islands. From the 1970 s until the mid-1990s, what had kept the territorial dispute between Tokyo and Beijing under control was a tacit agreement to "shelve the dispute." ${ }^{11}$ Nevertheless, since the mid-1990s Japanese politics has grown increasingly nationalistic and has resulted in flaring tensions in Asia. In 1996, soon after the Japanese government announced the two hundred nautical miles centering on the Senkaku Islands as the Japanese Exclusive Economic Zone (EEZ), a Japanese nationalist group rebuilt a lighthouse on one of the disputed islands, outraging Chinese nationalists in Taiwan and Hong Kong. The rise of Japanese right-wing 
nationalism became obvious when Shintaro Ishihara, who wrote a patriotic book entitled A Japan That Can Say No in 1989 and announced a plan by the Tokyo Metropolitan Government to purchase the Senkaku Islands in April 2012 and fortify them, was elected mayor of Tokyo in 1999. Since 2000, the Japanese government has increased police patrols of the disputed Senkaku Islands to give evidence of Japan's effective control. As a result of Japan's 2005 textbook screening, the number of references to the Senkaku Islands increased in the textbooks of primary and secondary schools to support an official statement about there being "no territorial problem" over the Senkaku Islands with Taiwan and China. ${ }^{12}$ For the CCP leadership, losing the tug-of-war over sovereignty of the Diaoyu Islands to Japan not only would undermine its legitimacy but also could jeopardize its economic interest in the massive oil deposits near the islands.

Meanwhile, the trajectory of Taiwan's future shifted closer toward independence following the victories of Lee Teng-hui in the 1996 presidential election and of the Democratic Progressive Party (DPP) in the two subsequent ones. During this period, the Taiwan government made only lukewarm statements to claim the ROC's sovereignty over the disputed islands. As Taiwanese nationalism became the top issue of the political platform, the enthusiasm for the movement to protect the Diaoyu Islands ran low. The issue of the Diaoyu Islands, which the younger generation in Taiwan associated with support for cross-Strait reunification, was labeled "politically incorrect." In 1996, the Japanese claim on the EEZ around the Diaoyu Islands led Lee Teng-hui to reiterate the ROC's sovereignty over the disputed islands, but he also set aside sovereignty disputes to enable fisheries negotiations with Japan. During the DPP period (2000-2008) as well, the Taiwanese government was more concerned to negotiate the historic fishing rights of Taiwanese fishermen around the disputed waters with Japan. In February 2005, a lighthouse that had been erected on the largest of the Diaoyu Islands by Japanese activists in 1978 came under Japanese government control. In June, Japan Coast Guard vessels chased away Taiwanese fishing boats, arousing protests among Taiwanese fishermen and Diaoyu Islands activists. In response to the anger of the fishermen, Chen Shui-bian sent out patrol ships to protect Taiwanese fishing boats and even set foot on the Pengjia Islet to claim Taiwan's sovereignty over the Diaoyu Islands. At the same time, he stated that the Taiwan government should handle the fishing rights issue separately from the sovereignty issue to avoid complicating the situation and escalating tensions. KMT legislators criticized Chen Shui-bian's response as merely "making a show," and Taipei's mayor, Ma Ying-jeou, said it showed a lack of courage.

After years of playing down the sovereignty issue, Taiwan and Japan finally made a diplomatic breakthrough in late August 2005. The Japanese Diet passed legislation to give Taiwanese a visa waiver but made no conciliatory offer to China. Hence, this move was seen as a break from Japan's balancing act on the cross-Strait issue. The sovereignty issue in Taiwan touched a raw nerve in China, particularly after 
Lee Teng-hui declared "special state-to-state relations" to define the relationship between Taiwan and China in 1999 and then declared-in a 2002 interview carried in a local daily in Okinawa Prefecture-that the Diaoyu Islands actually belonged to Japan. ${ }^{13}$ For China, reassertion of its sovereignty over the Diaoyu Islands became essential, as the islands were directly related to China's claim to Taiwan, and vice versa. National unity was essential to reinforce the CCP's legitimacy, which was in decline after the collapse of the Soviet Union. In short, various political changes in Japan and in Taiwan had eroded China's longtime policy of "shelving the dispute."

\section{The Construction of an Imagined Community through Linkages with Taiwan}

At the beginning of the twenty-first century, the CCP embarked on a deliberate publicity campaign to instill in Chinese youth the vision of the Diaoyu Islands as an inseparable Chinese territory. As in Japan, textbooks are in the front line of China's propaganda to stir up patriotism. In 2001, the PRC's Ministry of Education issued the Basic Education Curriculum Reform Outline (Trial), which put a central focus on the two dominant themes of Chinese patriotic education: Chinese tradition and history, and national unity and territorial integrity. ${ }^{14}$ Moreover, new teaching manuals published by the People's Education Press were changed to reflect the CCP's new stance on its territorial claims. For example, on the topic "Taiwan: Part of the Sacred Territory of China" in year 8's Geography I, teachers are encouraged to guide students through maps to identify places in Taiwan and islands affiliated with it, including the Diaoyu Islands. In "Geography of the Ocean" in the high school curriculum, the learning goal is to foster sovereignty consciousness by outlining China's natural ocean resources. To achieve that goal, the suggested teaching instruction is to discuss the illegal seizure of islands in the East and South China Seas and show how that poses a threat to China's interest and to its freedom of navigation. ${ }^{15}$ China is also embroiled in a map battle with Japan to support its historical claims and legal right over the Diaoyu Islands. Like all scholars on the subject, CCP officials cite a collection of historical maps dating back to the sixteenth century, which include the map Coastal Defense Stretching Thousands of Miles, showing that the Diaoyu Islands were incorporated into China's maritime defense in $1561 .^{16}$ Several other maps show the Diaoyu Islands serving as navigational aids for tributary missions between China and the Ryukyu Kingdom. The Great Universal Geographic Map drawn in 1767 shows that the Diaoyu Islands, as part of Taiwan's fishing grounds, were included in the territory of the Qing Empire. The Map of East China Sea Littoral States created by the French cartographer Pierre M. Lapie in 1809 colored Diaoyu Dao, Huangwei Yu, and Chiwei Yu the same color as Taiwan. Those maps are considered to have been created on the premise that the Diaoyu Islands were part of Chinese territory prior to the sixteenth century and were not terra nullius before 1885 , as claimed by Japan. 
Through discourses of mapping, the Diaoyu Islands as part of Chinese national community have made their way into the imagination of the young generation.

China also reinforced the concept of the Diaoyu Islands as an inherent part of the territory of the PRC through several practical actions designed to strengthen the PRC's claims over the disputed islands. In 2008, soon after Ma Ying-jeou took the oath of office as the president of the ROC, a Taiwanese fishing ship, the Lien Ho, sank following a collision with a Japan Coast Guard vessel near the Diaoyu Islands. The Ma administration immediately demanded a public apology and compensation for the Lien Ho, suspended fisheries negotiations, and recalled Hsu Shih-kai, Taiwan's envoy to Japan, who had handled bilateral ties between Taiwan and Japan in absence of an official diplomatic relationship, for a decade. The KMT legislators went further to organize a voyage to the disputed waters aboard a navy La Fayette frigate. DPP legislators saw these moves as paving the way to forging closer ties with Beijing because the first Chen-Chiang summit of cross-Strait meetings, after a decade-long stalemate between Taiwan and China, was to take place in a week in Beijing. For China, it was the beginning of an attempt to create a community of interest on the issue with Taipei. Four days after the cross-Strait summit, China sent two patrol boats to the East China Sea to challenge Japan's effective control for the first time. This act, covered to the saturation point by China's state-controlled media, marked a new phase in the troubled relationship between China and Japan, signifying the end of "shelving the dispute." Since 2010, when a Chinese fishing trawler collided with Japanese Coast Guard boats, China began to dispatch patrol ships to the disputed waters on a regular basis.

China has since gained more momentum on disputes over the Diaoyu Islands and has marginalized Taiwan's response on this issue. In August 2012, to affirm Taiwan's position on disputed waters, the Ma administration proposed the East China Sea Peace Initiative-a plan that aims at shelving disputes and peacefully resolving disputes in the East China Sea by reciprocal negotiation and cooperative development. The DPP regarded this initiative as supporting the one-China principle because it allowed the PRC to form a community of interest with Taiwan on the sovereignty claims over the Diaoyu Islands. However, the response from Beijing was less than enthusiastic. The director of China's Taiwan Affairs Office, Wang $\mathrm{Yi}$, commented - in a underwhelming way — that China was aware of the initiative but that China's standpoint on the East China Sea had always been crystal clear. To underline China's dominance on the issue of the Diaoyu Islands, Chinese state media and online censors downplayed coverage of the initiative.

\section{RESEARCH METHODS}

On September 11, 2012, a week before the eighty-first anniversary of the Manchurian incident, the Japanese government purchased three of the five Diaoyu Islands, 
causing uproar in as many as one hundred cities in China and sparking street protests of one million young people. Why did a piece of land on a map emerge as a powerful and attractive vision of Chinese youth nationalism in 2012? Why did national sentiments turn into a "rage" among Chinese youth?

\section{Conceptualization}

Answering these questions first requires defining Chinese nationalism, youth, and outrage. Consideration of the full range of scholarship on Chinese nationalism, which takes on different meanings at different junctures in Chinese history and for various scholars, is beyond this chapter's scope. In this study Chinese nationalism denotes patriotism, love, loyalty, and devotion to China. Youth refers to the post-1980 generation, or "millennials" who grew up witnessing China's reform and opening and who experienced the Tiananmen incident and the Patriotic Education Campaign. In theory, a group that shares "common historical memories due to the fact that they were born in the same period and lived through the same political and economic development" during adolescence is regarded as a "political generation." ${ }^{17}$ On the basis of this definition, the people in China can be divided into five political generations: the war generation (before 1943), the Cultural Revolution generation (1944-61), the Reform generation (1962-80), the post-1980 generation (1981-90), and the post-1990 generation (1991 to the present). Outrage in this study is defined as a feeling of righteous anger in defense of China's survival and prosperity.

\section{Data}

To explore its research questions, this chapter relies on three complementary forms of data. First, the Strong Nation Forum plays an integral part in this chapter's primary research. It is a Chinese bulletin board on the website of the People's Daily and was created in 1999 to serve as an outlet for Chinese anger over the US bombing of the Chinese Embassy in Belgrade. Soon after the Strong Nation Forum appeared online, it became the most important online forum for nationalist sentiments. As shown in the online survey conducted by the Liao wang dong fang zhou kan (Oriental outlook) in 2008, 68 percent of Internet users on the Strong Nation Forum belonged to the youth cohort aged twenty to forty.$^{18}$ In this regard, the Strong Nation Forum can serve as a valid unit of observation on Chinese youth nationalism. This study reviews and analyzes comments and discussions on the Strong Nation Forum during the 2008-15 period to understand Chinese youth nationalism, its emergence, and its evolution into anti-Japan nationalism in 2012. The data for the analysis were collected via a keyword search on the Strong Nation Forum for posts containing the term Diaoyu Islands. Repeated postings and similar posts by the same Internet users were deleted to limit the amount of spamming on the site or to avoid the attempt of prominent users to multiply their own 
opinions. In total, 1,355 valid posts regarding the Diaoyu Islands were collected for analysis. Content analysis was further used to analyze this text-based data set. To avoid the disadvantages of automated (fully computerized) content analysis that tends to make arbitrary associations between words and phrases and to overlook the context of each post, posts in this study were read and coded manually. ${ }^{19}$ We pulled as much information out of each post in a way that linked each of them to major themes and categorized them into cause, resolution, attitudes toward the CCP, Japan, the United States, and Taiwan, and so on (see table 6). Since content analysis is prone to coder bias, two coders coded and cross-checked the same data to ascertain the results' reliability. This study was complemented by two other data sources. First, it explored the online survey on patriotic and nationalistic attitudes that was conducted by the People's Daily in 2012 and 2013. Several characteristics of this data type were well suited for this research. Most obviously, the survey asked questions concerning individual autonomy and independent thinking for the post1980 generation. The final data source consisted of face-to-face interviews in China, conducted in 2012 by the World Values Survey, which tracks values and cultural change over time. The target population consisted of Chinese citizens over eighteen years old. Analyzing these three data sets enabled us to investigate the nature of Chinese nationalism and why Chinese youth nationalism erupted in 2012.

\section{Limitations of the Data}

Using the Strong Nation Forum as our unit of observation met with some skepticism regarding selection bias. Two factors contribute to possible bias. The first is that rural Internet penetration in China remained roughly 27.5 percent compared to 62 percent in urban areas in 2013. This led to the underrepresentation of rural youth in our sample. Although just over half of the rural population uses the Internet, a relatively larger percentage (55.3 percent) of them belong to the $20-40$ age bracket, almost two-thirds of the people in rural areas in 2013, similar to the ratio in the cities..$^{20}$ In this regard, we can rule out the first concern about selection bias. The second selection bias involves the Strong Nation Forum's management by the People's Daily, an organ of the CCP's Central Committee. The general guidelines of the Strong Nation Forum involve prohibitions and censorship of inciting subversion of state power, separatist movements, and illegal activities. ${ }^{21}$ Messages on sensitive topics such as Tiananmen and Falun Gong certainly cannot appear. If discussions are beyond the CCP's tolerance limits, webmasters will delete all postings and block the IP addresses and registered names. To some extent, freedom of speech on the Web is constrained, leading to a bias in public opinion. However, the government has been relatively tolerant toward online discussions that are critical of its policies but appeal to nationalist sentiments. The estimated deletion rate is about 1 to 1.5 percent. $^{22}$ Furthermore, as online political forums hosted by SINA, Tianya, and many other privately operated media have multiplied, is the CCP has become 
less likely to turn against Internet users with a zealous crackdown on the Strong Nation Forum. In general, the Strong Nation Forum is probably a good venue for observing Chinese youth nationalism because that is where it appears in great profusion. Using the online survey as research data might also encounter a self-selection bias. The problem is that since respondents are allowed to decide whether they want to participate in a survey, specific groups turn out to be overrepresented, such as youth cohorts, the middle class, and people with higher education. As a result, the respondents participating in online surveys will not represent the entire population. However, we can mitigate this concern about self-selection bias, since this study aims to study youth, not the general population.

\section{THE 2012 DIAOYU ISLANDS INCIDENT: A “RAGING YOUTH" PHENOMENON}

Why did Chinese youth nationalism revive and escalate in 2012? Despite the Chinese government's prohibition, Chinese Internet users launched a widespread campaign on the Web to boycott Japanese products, leading to a plunge in the sales of Japanese automobiles and consequently forcing Toyota and Honda to temporarily halt production in China. Did the movement simply reflect an imagined community or historical hatred revived in textbooks, or did it reflect national pride in China's exceptional economic growth, eager to transcend conditions of oppression?

\section{Driven by Ambivalence toward the CCP}

The empirical analysis shows the "raging youth" phenomenon to derive from ambivalence between national pride and disappointment in the CCP. As evident in the Strong Nation Forum (table 6), about 8.5 of the Internet posts mentioned that since ancient times China had had indisputable sovereignty over the Diaoyu Islands, now illegally occupied by Japan. As seen in the World Values Survey in 2012 (table 7), 91.4 percent of the post-1980 generation were proud of China, and 84.1 percent were willing to fight for China in the event of a war, with an average 15 percent higher than the previous two generations. However, regarding the 2012 Diaoyu Islands incident, the Strong Nation Forum (table 6) was flooded with messages expressing shame and disappointment in the CCP. Approximately 16.6 percent of the posts criticized the CCP for being "too soft" on Japan, specifically accusing the government officials and experts of failing to reassert sovereignty over the islands. Around 3.8 percent of the posts recognized the government's efforts of dispatching patrol ships to a disputed area but were concerned that the intention was to shift people's attention away from the economic slowdown. One user stated, "Sending patrol ships is just tiptoeing around the issue." What made the post-1980 generation proud yet ashamed?

In the early 1990s, the weakening hold of Chinese socialism due to China's market transition and the sudden collapse of the Soviet Union gave rise to the search 
TABLE 6 Opinions and attitudes on the Diaoyu Islands dispute

\begin{tabular}{|c|c|c|c|}
\hline Theme & Percentage & Subcategory & Percentage \\
\hline \multirow{4}{*}{ Sarcastic messages } & \multirow{4}{*}{19.2} & Controversial figures & 4.1 \\
\hline & & Mockery of the CCP & 5.0 \\
\hline & & $\begin{array}{l}\text { Boasting, bragging of plans to } \\
\text { seize islands }\end{array}$ & 3.5 \\
\hline & & Others & 6.6 \\
\hline Disappointment with CCP & 16.6 & & \\
\hline Awareness of patrol vessels & 3.8 & & \\
\hline $\begin{array}{l}\text { Diaoyu Islands as inseparable } \\
\text { from China }\end{array}$ & 8.5 & & \\
\hline \multirow{3}{*}{ Resolution by force } & \multirow{3}{*}{12.3} & Declaration of war & 6.9 \\
\hline & & Retrieve at any cost & 2.8 \\
\hline & & Inevitable war & 2.6 \\
\hline Resolution by talk & 4.3 & & \\
\hline \multirow[b]{2}{*}{ Taiwan factor } & & Unification as crucial & 4.3 \\
\hline & & $\begin{array}{l}\text { Taiwan must act to signal control } \\
\text { over Diaoyu Islands }\end{array}$ & 4.2 \\
\hline \multirow{2}{*}{ Japan’s responsibility } & \multirow{2}{*}{6.5} & Japan’s provocation & 1.9 \\
\hline & & Japan's ambition & 4.7 \\
\hline \multirow[t]{2}{*}{ US's responsibility } & \multirow[t]{2}{*}{12.3} & $\begin{array}{l}\text { Obama's foreign policy pivot } \\
\text { toward Asia }\end{array}$ & 6.1 \\
\hline & & Occupation of Okinawa & 6.2 \\
\hline \multirow{2}{*}{ Ethnic slurs } & \multirow{2}{*}{5.8} & Against Japan & 3.7 \\
\hline & & Against US & 2.1 \\
\hline \multirow{2}{*}{$\begin{array}{l}\text { Criticizing attitudes of Chinese } \\
\text { netizens toward Japan and US }\end{array}$} & \multirow{2}{*}{5.9} & $\begin{array}{l}\text { Calling pro-Japan and pro-US } \\
\text { attitudes unpatriotic }\end{array}$ & 2.1 \\
\hline & & $\begin{array}{l}\text { Calling anti-Japan and anti-US } \\
\text { attitudes irrational }\end{array}$ & 3.8 \\
\hline Others & 11.3 & & \\
\hline
\end{tabular}

SOURCE: Strong Nation Forum, bbs1.people.com.cn/.

for a new ideology. Announced in 1991 and fully functioning by 1994, patriotic education was initiated by Jiang Zemin in the hope of filling the ideological vacuum. The content of Chinese patriotic education, reviving patriotism as a replacement for diminishing socialism, had two dominant themes: Chinese tradition and history, and national unity and territorial integrity. Through patriotic education and educational reforms since 2001, the post-1980 Chinese have grown up embracing a commitment to safeguarding Chinese sovereignty and to defending territorial integrity. National identity for the Chinese youth was not simply evoked by a "nationalism of despair" that evoked memories of a former glory dashed by a 
TABLE 7 National pride and patriotism in China in 2012

\begin{tabular}{|c|c|c|c|c|c|c|c|}
\hline & & & \multicolumn{4}{|c|}{ Generation } & \multirow[b]{2}{*}{ Total } \\
\hline & & & $\begin{array}{c}\text { War } \\
\text { generation } \\
\text { (before } \\
\text { 1943) }\end{array}$ & $\begin{array}{c}\text { Cultural } \\
\text { Revolution } \\
\text { generation } \\
(1944-61)\end{array}$ & $\begin{array}{c}\text { Reform } \\
\text { generation } \\
(1962-80)\end{array}$ & $\begin{array}{l}\text { Post-1980 } \\
\text { generation } \\
(1981-90)\end{array}$ & \\
\hline \multirow{10}{*}{$\begin{array}{l}\text { How proud } \\
\text { of nationality }\end{array}$} & \multirow{2}{*}{ Very proud } & $\mathrm{N}$ & 41 & 124 & 212 & 123 & 500 \\
\hline & & $\%$ & 33.9 & 24.2 & 24.9 & 23.2 & 24.8 \\
\hline & \multirow[t]{2}{*}{ Quite proud } & $\mathrm{N}$ & 68 & 313 & 557 & 362 & 1300 \\
\hline & & $\%$ & 56.2 & 61.1 & 65.3 & 68.2 & 64.5 \\
\hline & \multirow[t]{2}{*}{ Not very proud } & $\mathrm{N}$ & 11 & 72 & 75 & 41 & 199 \\
\hline & & $\%$ & 9.1 & 14.1 & 8.8 & 7.7 & 9.9 \\
\hline & \multirow[t]{2}{*}{ Not at all proud } & $\mathrm{N}$ & 1 & 3 & 9 & 5 & 18 \\
\hline & & $\%$ & 0.8 & 0.6 & 1.1 & 0.9 & 0.9 \\
\hline & \multirow[t]{2}{*}{ Total } & $\mathrm{N}$ & 121 & 512 & 853 & 531 & 2017 \\
\hline & & $\%$ & 100.0 & 100.0 & 100.0 & 100.0 & 100.0 \\
\hline \multirow{6}{*}{$\begin{array}{l}\text { Willingness } \\
\text { to fight for } \\
\text { your country }\end{array}$} & \multirow[t]{2}{*}{ Yes } & $\mathrm{N}$ & 88 & 392 & 740 & 470 & 1690 \\
\hline & & $\%$ & 70.4 & 70.8 & 81.6 & 84.1 & 78.8 \\
\hline & \multirow[t]{2}{*}{ No } & $\mathrm{N}$ & 37 & 162 & 167 & 89 & 455 \\
\hline & & $\%$ & 29.6 & 29.2 & 18.4 & 15.9 & 21.2 \\
\hline & \multirow[t]{2}{*}{ Total } & $\mathrm{N}$ & 125 & 554 & 907 & 559 & 2145 \\
\hline & & $\%$ & 100.0 & 100.0 & 100.0 & 100.0 & 100.0 \\
\hline
\end{tabular}

SOURCE: World Values Survey in China (2012). WVS [World Values Survey], Wave 6 (2010-2014), China 2012, conducted by the Research Center for Contemporary China (RCCC) at Peking University in 2012. Data can be retrieved from www.worldvaluessurvey.org/WVSDocumentationWV6.jsp.

Nоте: \% in the parentheses is the row percentage.

subsequent "century of humiliation., ${ }_{23}$ Built on thirty years of economic reforms and opening to the world, China's remarkable economic growth boosted national confidence to an unprecedented level to underpin a new era of Chinese nationalism. Michel Oksenberg described it as a "confident nationalism," patient and moderate, rooted in the assurance that China could eventually regain its greatness through economic growth. ${ }^{24}$ By and large, post-1980 Chinese have believed in a strong China and the idea that "China can say no" to US hegemony and assert itself against other countries attempting to dominate it. Hence, seeing the Diaoyu Islands as a vital part of the motherland, many of the Internet users demanded tougher actions to defend them. Although 4.3 percent of the posts on the Strong Nation Forum voiced concern for a peaceful resolution through negotiations or economic sanctions, approximately 6.9 percent urged a declaration of war against Japan (table 6). "It is a piece of cake because we have nuclear weapons." Around 2.8 percent of the posts claimed that China should retrieve the islands at any cost, and 2.6 percent believed that war was inevitable. Some posts (4.3 percent) pointed 
out that the fundamental cause of the territorial dispute between China and Japan was Taiwan's status as an inalienable part of China. "To facilitate cross-Strait unification would make things easier." Taken together, 12.3 percent of the messages approved of using force to resolve the issue. In conclusion, as a consequence of patriotic education and China's exceptional growth, Chinese youth increasingly took pride in China's growing status and felt a strong obligation to defend China from hostile external forces.

Nevertheless, with China's integration into the world economy, it is not easy for China to say no. It is widely acknowledged that China's rapid integration into the global economy has heightened interstate conflicts. Simultaneously maintaining patriotism and prioritizing economic development has become especially difficult for the authorities in Beijing. ${ }^{25}$ In December 2003, Chinese premier Wen Jiabo used the term peaceful rise in his speech at Harvard University. ${ }^{26}$ Since then, a peaceful rise to power, backed up by economic development, has been the main priority of CCP leaders. The party has demonstrated its peaceful attitude by actively participating in international organizations, hosting the Olympic Games, and being involved in multilateral trade negotiations with as many as twelve countries. In 2012, at the eighteenth conference of the CCP, market pressures simultaneous with mainstream public demand for tough responses to Japan created a dilemma for Xi Jinping, the new general secretary of the CCP. As ongoing territorial disputes over the Diaoyu Islands have hampered the progress of the China-JapanSouth Korea Free Trade Agreement (FTA) negotiations, the return of the United States to the Asia-Pacific region has posed a critical challenge to China's political and economic clout. Specifically, negotiations have been under way since 2010 to create the US-led Trans-Pacific Partnership (TPP), which will be the world's largest free trade zone, in an attempt to contain China's rise. These efforts make more urgent the need for China to aggressively seek barrier-lowering FTAs with Japan and South Korea to harness the huge trade potential within ASEAN and across the Pacific Rim. China knows very well the cost of pushing Japan toward a military response. Although Chinese authorities have dispatched a marine surveillance plane and patrol vessels to enter the disputed waters to prove that Japan had no exclusive control over the islands, the CCP has since then made no attempt to land on the islands or to impose any economic sanctions against Japan. Many Chinese youth perceive the CCP's patrols and diplomatic gestures as "making shows of defiance," in Christopher Hughes's words. ${ }^{27}$ As a result, ambivalence toward the CCP has galvanized the post-1980 generation into action.

\section{Facilitated by the Rise of Network Society}

How can this proud generation minimize the anxieties associated with emotional conflicts between national pride and disappointment in the CPP's failure to live up to its nationalist rhetoric? As psychoanalysts point out, ontological uncertainties 
and existential anxiety have intensified the search for stable identities. Aggression and radical movements often develop as a consequence of anxieties and uncertainties. ${ }^{28}$ China's youth protest movements also show these dynamics. After three decades of economic reforms, the CCP still keeps a tight grip on political control. With a limited organizational life, sanctioned or monitored by the state, young people have been deprived of channels to vent their anger. While direct elections and party turnover are not allowed in the foreseeable future, young people also lack a public arena to express their dissatisfaction. To reach a stable state of coherent attitudes on the issue of the Diaoyu Islands, Chinese youth can shift from virtual reality to collective action.

To overcome the barriers to collective action in a large group, such as a nation, two kinds of tools are required-effective institutions to mobilize people toward collective ends and unifying ideas to convince people that they share a common fate. ${ }^{29}$ For the first tool, the advent of the Internet in China exerts a mobilizing influence by opening channels for civic engagement and the circulation of ideas. In the twenty-first century, Chinese modernization has led to a communications revolution. The rise of Internet-based communication heralds the emergence of a new form of communication: mass self-communication, which is "self-generated in content, self-directed in emission, and self-selected in reception by many that communicate with many." ${ }^{\circ}$ Individuals construct their own system of mass communication and asynchronous discussion through BBS, blogs, Weibo, Tencent QQ, and other social media- a development that has facilitated civic engagement and opened new channels for the circulation of ideas. The past decade has seen a tremendous increase in Internet use in China, with over six hundred million users in 2014. The Internet has become a virtual community for China's post-1980 generation, who account for nearly two-thirds of Internet users. ${ }^{31}$ Thus the Internet serves as a vehicle for Chinese youth to express and discuss national sentiments, as a means of fusing atomized individuals into a collectivity, and as a promoter pushing them toward protest activities.

With regard to the second tool, unifying ideas, the fast-growing educational system in China goes further to create unified fields of communication by using standardized languages and homogenized contexts with which to promote a common discourse of nationalism. As the statistics in 2014 show, higher education in China is continuously growing, with over two thousand universities and more than 7.27 million college graduates..$^{32}$ Education does more than cultivate loyalty to the state and the ruling party, or construct an imagined community to incorporate the Diaoyu Islands: it also produces a better-informed and more open-minded generation, increasing their ability to scrutinize the authenticity of information, engage in skepticism, and question authorities. Empirical evidence from the People's Daily online survey confirmed that 70 percent of the post-1980 generation perceived themselves as more independent thinking than older generations. 
In terms of action, in an online opinion poll on populism, also conducted by the People's Daily from October 21 to 31 in 2012, 42.8 percent of the post-1980 generation approved of radical movements for the sake of patriotism compared to 32.4 percent from earlier generations. ${ }^{33}$ These findings explain why vehement protests were sparked by Japan's purchase of the Diaoyu Islands in 2012, even though the government asked for calm and restraint. ${ }^{34}$ In other words, the effects of education are Janus-faced, for education does not simply stimulated patriotism in young people, it also creates mechanisms for them to correct the state when they feel that the government has strayed onto the wrong path. On the streets, young protesters shouted, "Never forget national humiliation" and "Protect China's inseparable territory," even venting their anger at the Chinese government, blaming it for being "shamefully weak," and urging it to "take Japan down."

\section{Reinforced by a Sense of Crisis}

Finally, why did protests over Diaoyu Islands turn violent? The resurgence of an outraged Chinese nationalism in 2012 can be explained by a strong sense of crisis. Many Strong Nation Forum posters believed that the United States was an even larger threat than Japan ("Of first importance now is the necessity to check the United States") and that it had been behind Japan's national resurgence. On the forum (table 6), 6.5 percent of posts expressed the belief that Japan should be held responsible for the dispute, whereas 12.3 percent held the United States responsible. About half of the posts that held the United States responsible (6.1 percent of the total sample) expressed the belief that Japan's nationalization of the Diaoyu Islands was a conspiracy of the United States to escalate tensions between Japan and China so as to advance itself across the Asia-Pacific. They pointed to the Treaty of Mutual Cooperation and Security between the United States and Japan, as well as USJapan joint military drills, to validate the posters' worries. They stated that Japan would not dare go to war without US endorsement. The other half (6.2 percent of total posts) looked to historical reasons for why the United States was to blame. For these Internet users, China's claims to the disputed Diaoyu Islands rested primarily on international contracts dating back to the 1943 Cairo Declaration, the 1945 Potsdam Proclamation, and the 1951 Treaty of San Francisco. However, the islands had never been returned to China because the Ryukyu Islands were under US administration at the end of the Second World War. "The Diaoyu Islands were used for US bombing practice to fulfill US greed," posted many Internet users. Many also believed that in the 1971 Okinawa Reversion Treaty the United States deliberately left the question of sovereignty over the Diaoyu Islands unresolved and ambiguous to this day, thereby opening a window for the United States to plant itself in Asia.

China's immediate concerns about the US threat may have been partly driven by new US foreign policies toward Asia. In 2011, the Obama administration 
declared that the United States would pivot back to Asia, a move that posed a critical challenge to China's political and economic clout. In economic terms, Obama came to the 2011 Asia-Pacific Economic Cooperation (APEC) summit to promote the TPP, which would forge a pathway to free trade across the Asia-Pacific and encompass 40 percent of the global GDP. The standards to join the TPP conformed to American conceptions of labor rights, intellectual property rights, and environmental protections that would strategically exclude China from the world's largest free trade zone. Not surprisingly, among hundreds of comments on the Strong Nation Forum, online posters unanimously regarded the TPP as an instrument for containing China's rise. Many Internet users perceived it as a "revival of US imperialism" and "US hegemony over the world." Power rivalry between the United States and China was further complicated in 2012, when the United States persuaded Japan to join TPP negotiations amid rising tensions with China over the Diaoyu Islands. At the same time, the United States clarified in a statement that the bilateral Treaty of Mutual Cooperation and Security covered the Diaoyu Islands and obliged the United States to defend them in the event of an armed attack. Later that same year, the United States and Japan began joint military exercises. The US expansion of its military involvement in Japan's conflict against China escalated concerns about an unstated US aim to block China, especially after Japan's Liberal Democratic Party won the House of Representatives elections by a landslide in December 2012, encouraging the new Japanese prime minister Shinzo Abe to more stridently push issues concerning the Diaoyu Islands. In 2013, the Abe government declared that joining the TPP would strengthen Japan's security. He continued to push ahead in reinterpreting Japan's constitution to authorize the right to collective self-defense.

China's youth perceive an immediate threat to China's existence in policies of economic and military containment by Japan and the United States, and their sense of crisis is grounded in the shared memory of China's century of humiliation and its isolation during the Cold War. From this sense of threat and crisis arise two mechanisms that reinforce their national identity and radicalize their actions. The first one is a clear enemy to target. Identity is about belonging, what you have in common with your own group, and what differentiates you from others. ${ }^{35}$ Hence, in forming identity, the first and foremost need is to define "others." It requires the establishment of a boundary between "us" and "them," and across this boundary differences between the groups are signaled. ${ }^{36}$ However, for young Chinese, it is difficult to form a clear sense of "us." During the Cultural Revolution an enormous number of cultural treasures and traditional values were eradicated. As stated by Lucian Pye, the building blocks for a coherent identity in China are missing because the symbols and ideals of the culture have been so severely damaged. The content of Chinese contemporary nationalism appears to be exceedingly thin, without shared ideas and 
worthy principles that can inspire people. ${ }^{37}$ Moreover, China's transition from communism to capitalism has led to a state of anomie in which young people suffer from a disbelief in socialism and a sense of powerlessness in the market economy. Accordingly, the new generation holds an insular attitude and loses meaningful connections to others. Hence, Chinese identity for the post-1980 generation had been unstable in and of itself, inasmuch as it was a result of state construction through patriotic education and state propaganda. Nevertheless, as international conflicts increase, Chinese youth become more aware of their membership in the Chinese nation in a sense of perceiving it as threatened and uniting against enemies. They begin to strengthen their Chinese identities in contrast to clear rivals-Japan and the United States.

The second mechanism that a sense of threat and crisis provides is the motivation for collective resistance. The Chinese have been fighting against deep-seated doubts about their ethnic dignity for a century. In spite of China's economic successes, the narrative of the "century of humiliation" has been reiterated in historical textbooks and official documents to remind people of the agonies and shame of foreign aggression. The Japan-US alliance, which young Chinese see as intended to contain the rise of China, threatens not only China's rise but its national dignity. In Gordon Allport's analysis, an enemy who threatens people's positive values stiffens their resistance and makes them exaggerate the merits of their cause. ${ }^{38}$ In the same vein, Chinese youth nationalism is found in unity against shared enemies-Japan and the United States-especially in a time of rapidly increasing Internet access. Verbal aggression on the Internet is the most convenient way to boost self-esteem by stigmatizing others. On the Strong Nation Forum (table 6), a handful of posts (5.8 percent) attacked the United States and Japan with derogatory words. They called Americans yang gui-zi (foreign devils) and added the new term mi-guo, insinuating a "rotten country." They also called the Japanese "dogs," "little Japan," gui-zi, and mostly wo kou (dwarf bandits), all of which are extremely pejorative ethnic slurs. Although the movement started with peaceful demonstrations, nationalist movements on a large scale aim at venting xenophobic sentiments easily go out of control. Despite the calls for peaceful protests and a prohibition of the boycott, Chinese Internet users launched a widespread campaign on the Web to boycott Japanese products, leading to a plunge in the sales of Japanese automobiles and consequently forcing Toyota and Honda to temporarily halt production in China. Why did Chinese youth nationalism turn into a hazard? From many transitional states, it is observed that the motivations behind ethnic violence are fear and insecurity, not hatred. ${ }^{39}$ The more insecure a person feels, the more violently he or she reacts. As a consequence of the immediate threat and the need to contain the US-Japan alliance advancing across the Pacific, China's xenophobic nationalism in 2012 spread more swiftly and epidemically than ever, and youth movements have shockingly caused near riots in large Chinese cities. 


\section{CONCLUSION}

In 2012, before the eighty-first anniversary of the Manchurian incident, tensions between China and Japan escalated sharply amid fiercely anti-Japan protests against Japan's nationalization of the Diaoyu Islands. This phenomenon attracted worldwide attention and rekindled the debate on the causes of Chinese nationalism. This study has gone beyond the hotly debated issue of whether Chinese nationalism has been instigated from the top down or has developed from the bottom up. It has investigated the psychological mechanisms that encourage Chinese youth nationalism. Through content analysis of the data gathered from the Strong Nation Forum, it has found three major reasons why Chinese youth nationalism in 2012 had taken on a violent character.

In 1972, the US transfer of administrative rights to Japan spawned disputes over the Diaoyu Islands. Both China and Taiwan held tenacious views about ownership of the Diaoyu Islands, considering them part of Taiwan. Hence, with the end of the Second World War, the Diaoyu Islands along with Taiwan should have been returned to Chinese jurisdiction. In the meantime, after the PRC replaced the ROC as China's representative in the United Nations, the weakening hold of Chinese identity gave rise to a search for a set of new policies to maintain the KMT's legitimacy. During periods of low public mobilization, one strategy of the KMT government was to use the Diaoyu Islands disputes to galvanize young Taiwanese into participating in nationalist movements. Meanwhile, Japan and China were in the midst of normalizing diplomatic relations. Although disputes ignited anger and indignant protests in Taiwan and Hong Kong, the CCP leadership avoided controversy over the issue throughout the 1970s, 1980s, and the 1990s. However, since the mid-199os, the resurgence of Japanese nationalism and Taiwanese nationalism has changed China's longtime policy of "shelving the dispute." In the face of new threats in international relations, Chinese youth nationalism was revived by the $\mathrm{CCP}$ as a replacement for diminishing socialism. At the dawn of the twenty-first century, the CCP initiated a program of patriotic education to assert its claim over Taiwan and the Diaoyu Islands. Through geography and history lessons at schools, Chinese young generations have been infused with the ideal of safeguarding territory unity. Through a propaganda war against Japan, Chinese young generations are visualizing Taiwan and its annexed islands-the Diaoyu Islands-as an inalienable part of China.

We then ask why protests to dispute Japanese claim to the Diaoyu Islands in 2012 turned violent. The first reason is rooted in ambivalence between national pride and disappointment in the CCP. Through patriotic education and on the basis of China's remarkable economic growth, the post-1980 generation has grown up believing in a strong China and in a mission of defending national unity. As evident in the World Values Survey in 2012, the post-1980 generation is more proud of being Chinese than other generations and is more willing to 
be dedicated to the country. However, in 2012, as the imbroglio of the Diaoyu Islands was ongoing, negotiations over a China-Japan-South Korea FTA were about to begin. In the meantime, the CCP was torn in different directions in the battles between economic interests and national sentiments. Many Chinese youth regarded the CCP's rhetorical protests as merely for show and believed that the CCP was actually putting economic interests ahead of national dignity. The Strong Nation Forum was overwhelmed with posts expressing disappointment in the CCP and demanding tough responses to Japan. Without elections to vent their anger, Chinese youth went out in the streets to express themselves and to mitigate their anxieties associated with emotions in conflict. With the advent of the Internet and enlightenment by education, rampant protests were widespread, despite the pressure of government suppression. Finally, Chinese "raging youth" nationalism is reinforced by its resistance to shared enemies. In 2012, youth protests were a reaction to Japan's nationalization of the Diaoyu Islands, whereas on the Strong Nation Forum many people believed that the United States had triggered Japan's aggressive nationalism and should be responsible for the 2012 Diaoyu Islands incident. China's concern about the US threat is highly related to US policies of containing China through the TPP and a military alliance with Japan. The conflict between China and the United States peaked in 2012, as the United States persuaded Japan to join the TPP amid simmering tensions over the disputed islands. A shared memory of China's century of humiliation and isolation during the Cold War has enhanced the sense of crisis with the sense of an immediate threat to China's existence. Chinese youth tend to strengthen their Chinese identities in contrast to clear enemies-Japan and the United States. The crisis of threat is the motivation for collective resistance as well. A shared enemy provides common cause for national unity. As a consequence of the immediate threat and the need to contain the US-Japan alliance advancing across the Pacific, China's xenophobic nationalism in 2012 spread swiftly. In the end, Chinese youth's identity was affirmed against the alien.

\section{NOTES}

1. Fenqing, as Wu defines it, refers to a large group of online Chinese users who detest anything conformist or foreign. They call for aggressive action against foreign pressure. See also Xu Wu, "Chinese Cyber Nationalism: How China's Online Public Sphere Affected Its Social and Political Transition" (PhD diss., University of Florida, 2005), 122.

2. Anomie, as defined by Durkheim, is a condition of societal instability that creates a sense of normlessness and purposelessness. See Émile Durkheim, Division of Labour in Society, trans. G. Simpson (Glencoe, IL: Free Press, 1947).

3. Xiancai Chen, "Why Is the Democratic Progressive Party Anxious about Cross-Strait Cooperation on the Baodiao Movement," Formosa, September 24, 2012, www.my-formosa.com/article. aspx? cid=5,6\&id $=32406$. 
4. H. Peter Gries, "Popular Nationalism and State Legitimation in China," in State and Society in 21st-Century China: Crisis, Contention, and Legitimation, ed. Peter H. Gries and Stanley Rosen (New York: Routledge, 2004), 188-91.

5. Suisheng Zhao, Nation-State by Construction: Dynamics of Modern Chinese Nationalism (Stanford, CA: Stanford University Press, 2004), 209-47.

6. Susan Shirk, China: Fragile Superpower: How China's Internal Politics Could Derail Its Peaceful Rise (New York: Oxford University Press, 2007), 164-65; Christopher R. Hughes, "Nationalism in Chinese Cyberspace," Cambridge Review of International Affairs 13, no. 2 (2000): 195-209.

7. Lowell Dittmer and Samuel S. Kim, "In Search of a Theory of National Identity", in China's Quest for National Identity, ed. Lowell Dittmer and Samuel S. Kim (Ithaca, NY: Cornell University Press, 1993), 1-31.

8. Gries, "Popular Nationalism," 183, 191.

9. Wu, "Chinese Cyber Nationalism," 150.

10. Shubo Li, "Configuring a Threatening Other: Historical Narratives in Chinese School Textbooks," in The Dispute over the Diaoyu/Senkaku Islands: How Media Narratives Shape Public Opinion and Challenge the Global Order, ed. Thomas A. Hollihan (New York: Palgrave Macmillan, 2014), 27-28.

11. Reinhard Drifte, "The Japan-China Confrontation over the Senkaku/Diaoyu Islands: Between 'Shelving' and 'Dispute Escalation," Asia-Pacific Journal 12, no. 30 (2014), www.japanfocus.org/Reinhard-Drifte/4154/article.html.

12. Hiroko Okuda, "Historical Narratives in Japanese School Textbooks," in Hollihan, Dispute, 63.

13. On July 23, 2015, during his trip to Japan, Lee Teng-hui sparked a firestorm in Taiwan by restating that the Senkaku Islands belonged to Japan. President Ma Ying-jeou published an article in the Washington Times harshly rebutting Lee's statement. See Ma Ying-jeou, "The Diaoyutai Islands: ROC Territory," Washington Times, August 23, 2015, www.washingtontimes.com/news/2015/aug/23/ ma-ying-jeou-diaoyutai-islands-are-republic-china/.

14. The objective of Basic Education Curriculum Reform Outline (Trial) is outlined in the government document "Basic Education No. 17," issued by the Ministry of Education of People's Republic of China in 2001. See also Suisheng Zhao, "A State-Led Nationalism: The Patriotic Education Campaign in Post-Tiananmen China," Communist and Post-Communist Studies 31, no. 3 (1998): 296; Christopher R. Hughes, "Interpreting Nationalist Texts: A Post-structuralist Approach," Journal of Contemporary China 14, no. 43 (2005): 254.

15. The People's Education Press is under the direct leadership of the Ministry of Education. It has become the national center for school textbooks, which are used in most of the provinces in China. For teaching guidelines for geography, see Cheng Cai, "Bian xie yi liu jiao cai tui jin su zhi jiao yu" [Producing first-class teaching materials and promoting teaching excellence], Kecheng Jiaocai Jiaofa / Curriculum, Teaching Material and Method 6 (June 200o): 1-5, www.pep.com.cn/gzdl/jszx/tbjxzy/pg/jxsj/xxe/.

16. For scholarship, see Kiyoshi Inoue, Senkaku Islands: A Historical Explanation of the Diaoyu Islands (Tokyo: Daisan shokan, 1996); Tianying Wu, Chia-wu chan-chein Tiao-yu-t'ai lieh-yu kuki-shu kao-Chien chih Jih-pen Ao-yuan Min-hsiung Chu Chiao-shu [A textual study on the ownership of the Diaoyu Islands prior to the Sino-Japanese War of 1894-95-Also a query to Professor Toshio Okuhara and others] (Beijing: Shehuei kexue wenxian chubanshe, 1994); Deyuan Ju, Rename Diaoyu Islands: Historical Sovereignty and International Law (Beijing: Kunlun chu ban she, 2006). In 2014, the State Oceanic Administration of the PRC set up an official website regarding the Diaoyu Islands, which provides the historical maps, legal documentation, and videos to support China's assertion that the Diaoyu Islands were Chinese territory before 1884; see www.diaoyudao.org.cn.

17. Karl Mannheim, "The Problem of Generations," in The New Pilgrims: Youth Protest in Transition, ed. Philip G. Altbach and Robert S. Laufer (New York: David Mckay, 1972), 276-332.

18. For the result, see "Wang luo gong min bu wan quan bao gao" [Incomplete report on netizens], Liao wang dong fang zhou kan, July 2008, http://bbs1.people.com.cn/post/2/1/2/87405005.html. 
19. William Lawrence Neuman, Social Research Methods: Qualitative and Quantitative Approaches (Boston: Allyn and Bacon, 1997), 275.

20. China Internet Network Information Center (CNNIC), Statistical Report on Internet Development in Rural China (Beijing: CNNIC, 2013), 6.

21. For the guidelines of the Strong Nation Forum, see Peoples Daily, http://bbsi.people.com.cn/ gltl.html.

22. Wenzhao Tao, "The Regulation of BBS in China People Daily," First Monday 6, no. 1 (January 8, 2001), http://journals.uic.edu/ojs/index.php/fm/article/view/826/735.

23. Lucien Bianco, Origins of the Chinese Revolution: 1915-1949 (Stanford, CA: Stanford University Press, 1971), 154.

24. Michel Oksenberg, "China’s Confident Nationalism," Foreign Affairs 65, no. 3 (December 1986): 501-23, 507 .

25. Chih-yu Shih, Navigating Sovereignty: World Politics Lost in China (London: Palgrave/Macmillan, 2003), 112-13; Shirk, China, 108-9.

26. Wen Jaibo, "Turning Your Eyes to China," speech at Harvard University, December 2003, transcript, www.people.com.cn/GB/shehui/1061/2241298.html.

27. Christopher R. Hughes, Chinese Nationalism in the Global Era (Abingdon: Routledge, 2006), 140.

28. K. Lewin, Resolving Social Conflicts (New York: Harper, 1948); Catarina Kinnvall, "Globalization, Identity, and the Search for Chosen Traumas," in The Future of Identity: Centennial Reflections on the Legacy of Erik Erikson, ed. Kenneth Hoover (Lanham, MD: Lexington Books, 2004), 111-36.

29. Jack Snyder, From Voting to Violence (New York: Norton, 2000).

30. Manuel Castells, "Communication, Power and Counter-power in the Network Society," International Journal of Communication 1 (2007): 238-66.

31. For more details on Chinese Internet users, see CNNIC [China Internet Network Information Center], "Ji chu shu ju" [Basic statistics], June 30, 2014, www.cnnic.cn/hlwfzyj/jcsj/.

32. National Bureau of Statistics in China, "Gao deng xue xiao pu tong ben zhuan ke xue xiao he xue sheng qing kuang" [The distribution of schools and students in the higher education system], 2014, http://data.stats.gov.cn/easyquery.htm? cn=Co1.

33. For the survey report, see "Zhong guo gong zhong de min cui hua qing xiang diao cha bao gao" [A report on the populist orientation of Chinese people," People's Daily, December 6, 2012, http:// theory.people.com.cn/n/2012/1206/c49152-19807772-1.html.

34. See "Ren min wang ping: Wo men zen yang bao wei Diaoyu Dao" [People's online comments: How can we protect the Diaoyu Islands," People's Daily, September 17, 2012, http://edu.people.com. $\mathrm{cn} / \mathrm{n} / 2012 / 0917 / \mathrm{c1053-19026485.html.}$

35. J. Weeks, "The Value of Difference," in Identity: Community, Culture, Difference, ed. Jonathan Rutherford (London: Lawrence and Wishart, 1990), 88.

36. Fredrik Barth, Ethnic Groups and Boundaries (Boston: Little, Brown, 1969); Henri Tajfel, The Social Psychology of Minorities, Report No. 38 (London: Minority Rights Group, 1978), 9.

37. Lucian W. Pye, "How China's Nationalism Was Shanghaied," Australian Journal of Chinese Affairs 29 (January 1993): 107-33.

38. Gordon Allport, The Nature of Prejudice (Cambridge, MA: Addison-Wesley, 1954).

39. Anthony Oberschall, "The Manipulation of Ethnicity: From Ethnic Cooperation to Violence and War in Yugoslavia," Ethnic and Racial Studies 23, no. 6 (2000): 982-1001. 
